\title{
The Inhalation Anesthetic Isoflurane Induces a Vicious Cycle of Apoptosis and Amyloid $\beta$-Protein Accumulation
}

\author{
Zhongcong Xie, ${ }^{1,2}$ Yuanlin Dong, ${ }^{1,2}$ Uta Maeda, ${ }^{1,2}$ Robert D. Moir, ${ }^{1}$ Weiming Xia, ${ }^{3}$ Deborah J. Culley, ${ }^{4}$ Gregory Crosby, ${ }^{4}$ \\ and Rudolph E. Tanzi ${ }^{1}$ \\ ${ }^{1}$ Genetics and Aging Research Unit, MassGeneral Institute for Neurodegenerative Disease, and Department of Neurology, Massachusetts General Hospital \\ and Harvard Medical School, Charlestown, Massachusetts 02129-2060, ${ }^{2}$ Department of Anesthesia and Critical Care, Massachusetts General Hospital and \\ Harvard Medical School, Boston, Massachusetts 02114, and 3 Center for Neurologic Diseases and ${ }^{4}$ Department of Anesthesia, Brigham and Women's \\ Hospital and Harvard Medical School, Boston, Massachusetts 02115
}

The anesthetic isoflurane has been reported to induce apoptosis and increase $\mathrm{A} \beta$ generation and aggregation. However, the molecular mechanism underlying these effects remains unknown. We therefore set out to assess whether the effects of isoflurane on apoptosis are linked to amyloid $\beta$-protein $(\mathrm{A} \beta)$ generation and aggregation. For this purpose, we assessed the effects of isoflurane on $\beta$-site amyloid $\beta$ precursor protein (APP)-cleaving enzyme (BACE) and $\gamma$-secretase, the proteases responsible for A $\beta$ generation. We also tested the effects of inhibitors of $\mathrm{A} \beta$ aggregation (iA $\beta 5$, a $\beta$-sheet breaker peptide; clioquinol, a copper-zinc chelator) on the ability of isoflurane to induce apoptosis. All of these studies were performed on naive human H4 neuroglioma cells as well as those overexpressing APP (H4-APP cells). Isoflurane increased the levels of BACE and $\gamma$-secretase and secreted A $\beta$ in the H4-APP cells. Isoflurane-induced A $\beta$ generation could be blocked by the broad-based caspase inhibitor Z-VAD. The A $\beta$ aggregation inhibitors, iA $\beta 5$ and clioquinol, selectively attenuated caspase- 3 activation induced by isoflurane. However, isoflurane was able to induce caspase-3 activation in the absence of any detectable alterations of $\mathrm{A} \beta$ generation in naive $\mathrm{H} 4$ cells. Finally, $\mathrm{A} \beta$ potentiated the isoflurane-induced caspase- 3 activation in naive $\mathrm{H} 4$ cells. Collectively, these findings suggest that isoflurane can induce apoptosis, which, in turn, increases BACE and $\gamma$-secretase levels and A $\beta$ secretion. Isoflurane also promotes $A \beta$ aggregation. Accumulation of aggregated $A \beta$ in the media can then promote apoptosis. The result is a vicious cycle of isoflurane-induced apoptosis, $\mathrm{A} \beta$ generation and aggregation, and additional rounds of apoptosis, leading to cell death.

Key words: Alzheimer's disease; APP; A $\beta$; apoptosis; anesthesia; isoflurane

\section{Introduction}

Alzheimer's disease (AD), the most common form of age-related dementia, is a rapidly growing health problem. Amyloid $\beta$-protein $(\mathrm{A} \beta)$ production and/or accumulation are major pathological hallmarks of AD (Glenner and Wong, 1984) (for review, see Tanzi and Bertram, 2005). A $\beta$ is produced via serial proteolysis of the amyloid $\beta$ precursor protein (APP) by aspartyl protease $\beta$-site APP-cleaving enzyme (BACE) or $\beta$-secretase and $\gamma$-secretase. BACE cleaves APP to generate a 99-residue membrane-associated C-terminal fragment (CTF) (APP-C99). APP-C99 is further cleaved by $\gamma$-secretase to release $4 \mathrm{kDa} \mathrm{A} \beta$ and $\operatorname{AICD}$ ( $\beta$-amyloid precursor protein intracellular domain) (Gu et al., 2001; Sastre et al., 2001; Yu et al., 2001). Presenilin (PS) and

Received Dec. 8, 2006; revised Dec. 27, 2006; accepted Dec. 30, 2006.

This work was supported by National Institutes of Health (NIH) Grants R01AG 014713 and R01MH 60009 (R.E.T.); NIH Grants K12AG 000294, K08 NS048140, and P60 AG008812 and the American Geriatrics Society Jahnigen Award (Z.X.); NIH Grant K08GM077057 (D.J.C.); and NIH Grant R01AG20253 (G.C.). The cost of anesthetic isoflurane and salary support of Yuanlin Dong and Uta Maeda were generously provided by the Department of Anesthesia and Critical Care, Massachusetts General Hospital and Harvard Medical School (Boston, MA).

Correspondence should be addressed to Dr. Rudolph E. Tanzi, Genetics and Aging Research Unit, MassGeneral Institute for Neurodegenerative Disease, and Department of Neurology, Massachusetts General Hospital and Harvard Medical School, 114 16th Street, C3009, Charlestown, MA 02129-4404. E-mail: tanzi@helix.mgh.harvard.edu. DOI:10.1523/JNEUROSCI.5320-06.2007

Copyright $\odot 2007$ Society for Neuroscience $\quad$ 0270-6474/07/271247-08\$15.00/0 $\gamma$-secretase cofractionate as a detergent-sensitive, highmolecular-weight complex ( $\mathrm{Li}$ et al., 2000) that includes at least three other proteins, nicastrin/anterior pharynx defective protein 2 (APH-2), APH-1, and presenilin enhancer protein 2 (PEN-2), all of which are necessary and sufficient for $\gamma$-secretase activity (Yu et al., 2000; Francis et al., 2002; Steiner et al., 2002). Increasing evidence suggests a role for caspase activation and apoptotic cell death in $\mathrm{AD}$, as well as in a large number of other neurodegenerative disorders, such as Huntington's disease, amyotrophic lateral sclerosis, and spinocerebellar ataxia (Holtzman and Deshmukh, 1997; Lunkes et al., 1998; Namura et al., 1998). A $\beta$ has been shown to cause caspase activation and apoptosis, which can in turn potentiate A $\beta$ generation (LeBlanc, 1995; Guo et al., 1997; Galli et al., 1998; Gervais et al., 1999; LeBlanc et al., 1999; Pillot et al., 1999; Sponne et al., 2003; Tesco et al., 2003; Sodhi et al., 2004; Kriem et al., 2005; Florent et al., 2006). Finally, fibrillar aggregates of $A \beta$ and oligomeric species of $A \beta$ are more neurotoxic (Pike et al., 1993; Lorenzo and Yankner, 1994; Lambert et al., 1998; Grace et al., 2002; Walsh et al., 2002; Wang et al., 2002; Kayed et al., 2003; Kim et al., 2003; De Felice et al., 2004).

Perioperative factors, including hypoxia (Kokmen et al., 1996; Jendroska et al., 1997; Nagy et al., 1997; Snowdon et al., 1997; Kalaria, 2000), hypocapnia (Xie et al., 2004), and anesthetics 
(Eckenhoff et al., 2004; Xie et al., 2006a), have been reported to potentially contribute to $\mathrm{AD}$ neuropathogenesis. These perioperative factors may also cause postoperative cognitive dysfunction, a dementia associated with surgery and anesthesia, by trigging $\mathrm{AD}$ neuropathogenesis. Treatment with a commonly used inhalation anesthetic isoflurane (1.2-2.5\% for $6 \mathrm{~h}$ ) has been shown to enhance $A \beta$ aggregation and cytotoxicity in pheochromocytoma cells (Eckenhoff et al., 2004). We recently showed that a clinically relevant concentration (2\%) of isoflurane can induce apoptosis, alter APP processing, and increase production of $\mathrm{A} \beta$ in $\mathrm{H} 4 \mathrm{hu}-$ man neuroglioma cells (Xie et al., 2006a).

Given these observations, we set out to determine the relationship between isoflurane-induced apoptosis and $\mathrm{A} \beta$ generation/ aggregation. More specifically, we addressed the hypothesis that isoflurane induces a vicious cycle of apoptosis, $A \beta$ generation, $A \beta$ aggregation, and additional rounds of apoptosis and $\mathrm{A} \beta$ production.

\section{Materials and Methods}

Cell lines. We used $\mathrm{H} 4$ human neuroglioma cells (naive $\mathrm{H} 4$ cells) and $\mathrm{H} 4$ human neuroglioma cells stably transfected to express full-length (FL) APP (H4-APP cells) in the experiments. All cell lines were cultured in DMEM (high glucose) containing 9\% heat-inactivated fetal calf serum, $100 \mathrm{U} / \mathrm{ml}$ penicillin, $100 \mu \mathrm{g} / \mathrm{ml}$ streptomycin, and $2 \mathrm{~mm}$ L-glutamine. Stably transfected H4 cells were additionally supplemented with 200 $\mu \mathrm{g} / \mathrm{ml} \mathrm{G} 418$.

Cell treatment. The cells were treated with $21 \% \mathrm{O}_{2}, 5 \% \mathrm{CO}_{2}$, and $2 \%$ isoflurane as described by Xie et al. (2006a). In the interaction studies, the cells were treated with Z-VAD $(100 \mu \mathrm{M}), \mathrm{A} \beta(2.5,5$, and $7.5 \mu \mathrm{M}), \mathrm{iA} \beta 5$ $(1.5 \mu \mathrm{g} / \mu \mathrm{l})$, and clioquinol $(1 \mu \mathrm{M}) 1 \mathrm{~h}$ before the treatment with $2 \%$ isoflurane or $100 \mathrm{~nm}$ staurosporine (STS). Control conditions included $5 \% \mathrm{CO}_{2}$ plus $21 \% \mathrm{O}_{2}$, which did not affect caspase-3 activation, cell viability, APP processing, and $\mathrm{A} \beta$ generation (data not shown).

Cell lysis and protein amount quantification. Cell pellets were detergent extracted on ice using immunoprecipitation buffer ( $10 \mathrm{~mm}$ Tris- $\mathrm{HCl}, \mathrm{pH}$ 7.4, $150 \mathrm{~mm} \mathrm{NaCl}, 2$ mм EDTA, and 0.5\% Nonidet P-40) plus protease inhibitors $(1 \mu \mathrm{g} / \mathrm{ml}$ aprotinin, $1 \mu \mathrm{g} / \mathrm{ml}$ leupeptin, and $1 \mu \mathrm{g} / \mathrm{ml}$ pepstatin A). The lysates were collected, centrifuged at 12,000 rpm for $10 \mathrm{~min}$, and quantified for total proteins by the BCA protein assay kit (Pierce, Iselin, NJ).

Western blot analysis. The cells were harvested at the end of the experiments and were subjected to Western blot analyses as described by Xie et al. (2005a). Antibodies A8717 (1:2000; Sigma, St. Louis, MO) and anti$\beta$-actin (1:5000; Sigma) were used to visualize APP-FL (110 kDa), APP-CTFs $(10-12 \mathrm{kDa})$, and $\beta$-actin $(42 \mathrm{kDa})$, respectively. A caspase-3 antibody (1:1000 dilution; Cell Signaling Technology, Beverly, MA) was used to recognize the caspase- 3 fragment $(17-20 \mathrm{kDa})$ resulting from cleavage at aspartate position 175 and caspase-3 FL (35-40 kDa). Rabbit polyclonal anti-BACE-1 antibody ab2077 (1:1000; Abcam, Cambridge, MA) was used to detect the protein levels of BACE ( $65 \mathrm{kDa})$. Antibody anti-nicastrin (1:1000; Calbiochem, La Jolla, CA) was used to detect nicastrin levels. The quantitation of Western blots was performed as described by Xie et al. (2005a). Briefly, the intensity of signals was analyzed by using an NIH Image program (NIH Image 1.62). We quantified the Western blots using two steps. First, we used the levels of $\beta$-actin to normalize (e.g., determining the ratio of APP-FL amount to $\beta$-actin amount) the levels of APP-FL, APP-CTFs, FL-caspase-3, caspase-3 fragment, BACE, and nicastrin to control for the loading differences in total protein amounts. Second, we presented the changes in the levels of APPFL, APP-CTFs, FL-caspase-3, caspase-3 fragment, and nicastrin in the cells treated with isoflurane, $\mathrm{Z}-\mathrm{VAD}, \mathrm{iA} \beta 5$, clioquinol, and $\mathrm{A} \beta$ as the percentage of those in the cells treated with controls. In this study, $100 \%$ caspase-3 activation, APP-FL, APP-CTFs, BACE, and nicastrin refer to control levels for the purpose of comparison with experimental conditions.

Quantitation of $A \beta$ using sandwich ELISA assay. Secreted $A \beta$ was measured with a sandwich ELISA assay by using an $A \beta$ measurement kit (Invitrogen, Carlsbad, CA) and by the $\mathrm{A} \beta$ ELISA Core Facility at the Center for Neurological Diseases, Brigham and Women's Hospital, Harvard Medical School (Boston, MA), as described by Xie et al. (2005b). Specifically, 96-well plates were coated with mouse monoclonal antibodies specific to $\mathrm{A} \beta_{40}$ ( $\beta$-amyloid [1-40] cleavage site-specific antibody) or $\mathrm{A} \beta_{42}$ ( $\beta$-amyloid [1-42] cleavage site-specific antibody). After blocking with Block Ace, wells were incubated overnight at $4^{\circ} \mathrm{C}$ with test samples of conditioned cell culture media, and then an anti-A $\beta(\alpha-\mathrm{A} \beta-\mathrm{HR} 1)$ conjugated to horseradish peroxidase was added. Plates were then developed with tetramethylbenzidine reagent, and well absorbance was

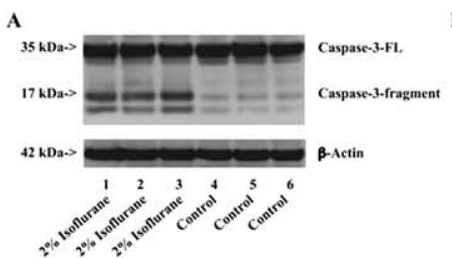

B

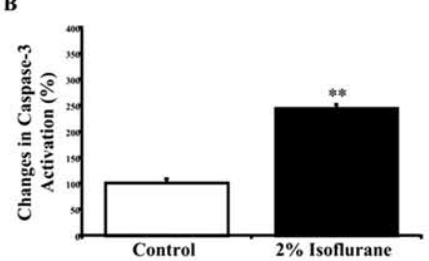

D

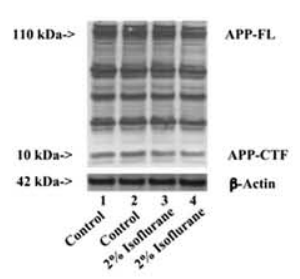

E

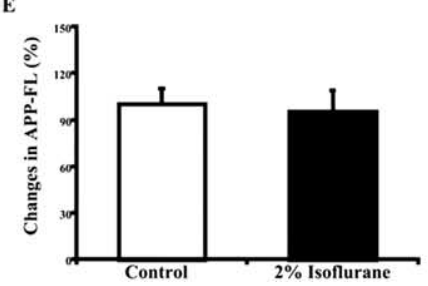

C

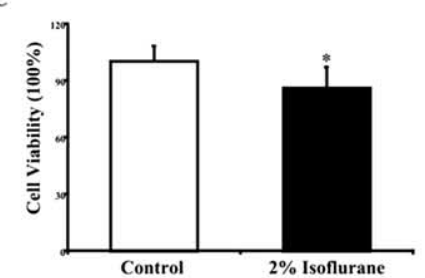

F

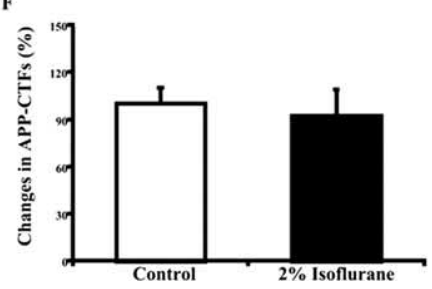

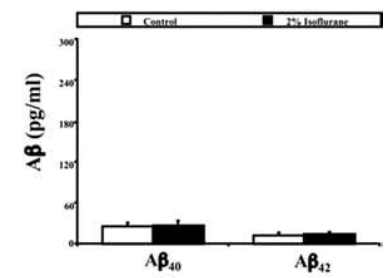

Figure 1. Treatment with $2 \%$ isoflurane induces caspase- 3 activation and decreases cell viability without detectable changes in APP processing and A $\beta$ generation in naive $H 4$ cells. $\boldsymbol{A}$, The $2 \%$ isoflurane treatment (lanes 1-3) induces caspase-3 cleavage (activation) compared with control conditions (lanes $4-6$ ) in naive $H 4$ cells. There is no significant difference in the amounts of $\beta$-actin between the control- or $2 \%$ isoflurane-treated naive $\mathrm{H} 4$ cells. $\boldsymbol{B}$, Caspase-3 activation assessed by quantifying the ratio of caspase-3 fragment to caspase-3-FL in the Western blots. Quantification of the Western blot shows that the $2 \%$ isoflurane treatment (black bar) increases caspase-3 activation compared with control conditions (white bar), normalized to $\beta$-actin levels. $C$, Treatment with $2 \%$ isoflurane (black bar) decreases cell viability compared with control conditions (white bar) in naive H4 cells. D, Treatment with $2 \%$ isoflurane (lanes 3,4 ) does not alter the levels of APP-FL and APP-CTFs compared with control conditions (lanes 1, 2). There is no significant difference in the amounts of $\beta$-actin in the control-or $2 \%$ isoflurane-treated naive $H 4$ cells. $\boldsymbol{E}$, Quantification of the Western blot shows that the $2 \%$ isoflurane treatment (black bar) does not alter the protein levels of APP-FL compared with control conditions (white bar) in $\mathrm{H} 4$ naive cells, normalized to $\beta$-actin levels. $\boldsymbol{F}$, Quantification of the Western blot shows that the $2 \%$ isoflurane treatment (black bar) does not alter the protein levels of APP-CTFs compared with control conditions (white bar) in $\mathrm{H} 4 \mathrm{naive}$ cells, normalized to $\beta$-actin levels. G, Treatment with $2 \%$ isoflurane (black bar) does not increase the generation of $A \beta_{40}$ and A $\beta_{42}$ compared with control conditions (white bar). Data are means \pm SD; $n=9-10$ for each experimental group. $t$ test was used to compare the difference between control condition and the $2 \%$ isoflurane treatment condition $\left({ }^{*} p<0.05\right.$; $\left.{ }^{* *} p<0.01\right)$. 


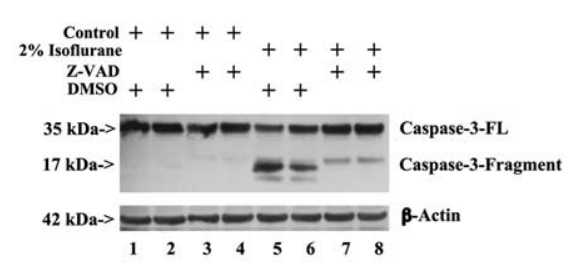

C

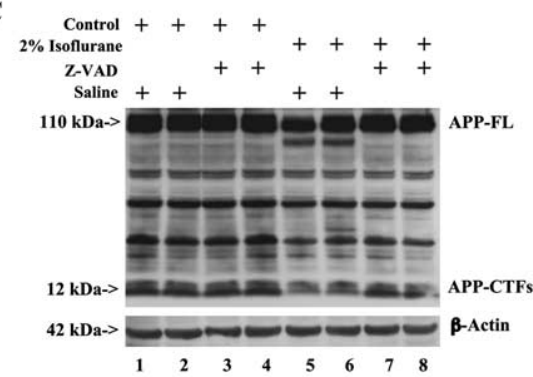

E

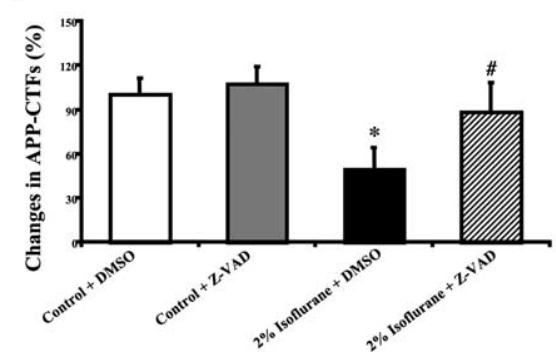

F

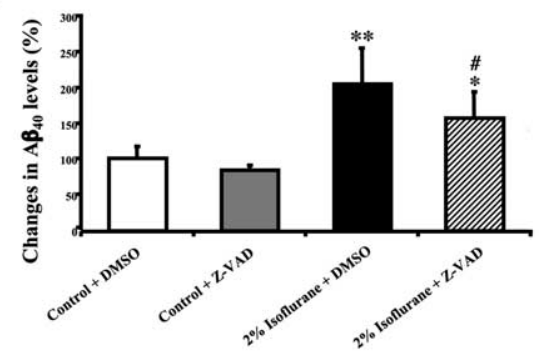

Figure 2. The caspase inhibitor Z-VAD inhibits the caspase-3 activation and the increases in A $\beta$ generation induced by $2 \%$ isoflurane in H4-APP cells. A, Treatment with $2 \%$ isoflurane (lanes 5,6 ) induces caspase-3 cleavage (activation) compared with control conditions (lanes 1, 2) or Z-VAD (100 $\mu \mathrm{m}$ ) treatment (lanes 3, 4). The Z-VAD treatment inhibits the caspase-3 cleavage induced by $2 \%$ isoflurane (lane 7,8). There is no significant difference in the amounts of $\beta$-actin in the H4-APP cells with the above treatments. $\boldsymbol{B}$, Quantitation of the Western blot shows that the $2 \%$ isoflurane treatment (black bar) increases caspase- 3 activation compared with control conditions (white bar) or the Z-VAD (100 $\mu \mathrm{m})$ treatment (gray bar), normalized to $\beta$-actin levels. The isoflurane-induced caspase-3 activation is inhibited by the Z-VAD treatment (striped bar). C, Z-VAD inhibits the isoflurane-induced changes in APP processing in H4-APP cells. Treatment with 2\% isoflurane (lanes 5,6) decreases the protein levels of APP-FL and APP-CTFs compared with control conditions (lanes 1, 2) or Z-VAD (100 $\mu \mathrm{M})$ treatment (lanes 3, 4). The Z-VAD treatment (lanes 7 , 8) inhibits the isoflurane-induced decreases in the protein levels of APP-FL and APP-CTFs. There is no significant difference in the amounts of $\beta$-actin in the H4-APP cells with all of the above treatments. D, Quantification of the Western blot shows that $2 \%$ isoflurane treatment (black bar) decreases the protein levels of APP-FL compared with the control condition (white bar) or Z-VAD treatment (gray bar), normalized to $\beta$-actin levels. The isoflurane-induced decrease in the protein levels of APP-FL is inhibited by the Z-VAD treatment (striped bar). $\boldsymbol{E}$, Quantification of the Western blot also shows that $2 \%$ isoflurane treatment (black bar) decreases the protein levels of APP-CTFs compared with the control condition (white bar) or Z-VAD treatment (gray bar), normalized to $\beta$-actin levels. The isoflurane-induced decrease in the protein levels of APP-CTFs is also inhibited by the Z-VAD treatment (striped bar). $F$, Z-VAD inhibits the isoflurane-induced increases in A $\beta$ generation. Treatment with $2 \%$ isoflurane (black bar) increases the levels of $A \beta_{40}$ compared with the control condition (white bar). Z-VAD treatment alone (gray bar) does not change the levels of $A \beta_{40}$; however, Z-VAD treatment inhibits the isoflurane-induced increases in the levels of $A \beta_{40}$. Data are means \pm $\mathrm{SD} ; n=6$ for each experimental group. $t$ test is used to compare the difference between control conditions and $2 \%$ isoflurane treatment $\left({ }^{*} p<0.05 ;{ }^{* *} p<0.01\right)$ and the difference between $2 \%$ isoflurane plus DMSO treatment and $2 \%$ isoflurane plus Z-VAD treatment $\left({ }^{\#} p<0.05 ;{ }^{\# \#} p<0.01\right)$.

measured at $450 \mathrm{~nm}$. A $\beta$ levels in test samples were determined by comparison with the signal from unconditioned media spiked with known quantities of $\mathrm{A} \beta_{40}$ and $\mathrm{A} \beta_{42}$.

Cell viability study. The cell viability was determined by using 3-[4,5dimethylthiazol-2-yl]-2,5-diphenyl tetrazolium bromide (MTT; Sigma). The experiments were performed according to the manufacturer's protocol. Briefly, we added $150 \mu$ l of MTT solution to each well, containing $1.5 \mathrm{ml}$ of cell culture media, of a six-well plate. We then returned the cell culture to the incubator for $2 \mathrm{~h}$. Finally, we removed the cell culture fluid and added $1.5 \mathrm{ml}$ of isopropanol into the wells. We spectrophotometri- cally measured the absorbance at a wavelength of $570 \mathrm{~nm}$. We present the changes in the absorbance, as a measure of cell viability, in the cells treated with isoflurane as the percentage of those in the cells treated with control conditions.

Statistics. Given the presence of background caspase- 3 activation and cell death in cells cultured in serum-free media, we did not use absolute values to describe changes in caspase- 3 activation and cell viability. Instead, changes in caspase- 3 activation and cell viability were presented as a percentage of those of the control group. One-hundred percent caspase- 3 activation or cell viability refers to control levels for purposes of comparison with experimental conditions. Data were expressed as mean $\pm \mathrm{SD}$. The number of samples varied from three to 10 , and the samples were normally distributed. We used a two-tailed $t$ test to compare the difference between the experimental groups. $p$ values $<0.05$ and 0.01 were considered statistically significant.

\section{Results}

\section{Isoflurane can induce caspase-3} activation in naive $\mathrm{H} 4$ cells

We previously reported that isoflurane can induce apoptosis and potentiate $\mathrm{A} \beta$ levels in the conditioned media of H4APP cells (Xie et al., 2006a). To test whether isoflurane can induce apoptosis in cells with low (barely detectable) basal levels of secreted $\mathrm{A} \beta$, naive $\mathrm{H} 4$ human neuroglioma cells were treated with $2 \%$ isoflurane for $6 \mathrm{~h}$. Because caspase- 3 activation is one of the final steps of cellular apoptosis (Thornberry, 1998), we assessed the effects of isoflurane on caspase- 3 activation by quantitative Western blot analyses. Isoflurane treatment led to caspase-3 activation (Fig. $1 A, B$ ), as evidenced by increased ratios of cleaved (activated) caspase-3 fragment (17-19 $\mathrm{kDa})$ to $\mathrm{FL}$ caspase-3 $(35-40 \mathrm{kDa})$. Quantitation of the Western blots, based on the ratio of caspase-3 fragment to FL caspase-3, revealed that the $2 \%$ isoflurane treatment (Fig. 1 B, black bar) led to a $240 \%$ increase in caspase-3 activation compared with control cells (Fig. $1 B$, white bar, ${ }^{*} p<$ 0.01 ). Treatment with $2 \%$ isoflurane (Fig. $1 C$, black bar) also decreased cell viability by $17 \%$ compared with the control cells (Fig. $1 C$, white bar, ${ }^{\star} p<0.05$ ). APP immunoblotting revealed no significant differences in the levels of APP-CTFs and APP-FL between $2 \%$ isoflurane-treated (Fig. $1 D$, lanes 3, 4; E, F, black bar) and control (Fig. $1 D$, lanes 1 , 2; $E, F$, white bar) naive $\mathrm{H} 4$ cells. Treatment with $2 \%$ isoflurane (black bar) did not increase levels of $A \beta_{40}$ (27 vs $30 \mathrm{pg} / \mathrm{ml}$ ) or $\mathrm{A} \beta_{42}$ (7 vs $9 \mathrm{pg} / \mathrm{ml}$ ) compared with the control cells (white bar) (Fig. $1 G$ ). These results suggest that the isoflurane can induce apoptosis independently of changes in APP processing and A $\beta$ generation in naive $\mathrm{H} 4$ cells. Collectively, these findings suggest that isoflurane can induce apoptosis/caspase activation in the 
absence of any significant alterations in $\mathrm{APP}$ processing and $\mathrm{A} \beta$ generation.

Isoflurane-induced alterations in APP processing and $\mathrm{A} \boldsymbol{\beta}$ generation can be attenuated by the caspase inhibitor $\mathrm{Z}-\mathrm{VAD}$ in H4-APP cells

We reported previously that isoflurane can alter APP processing and increase $A \beta$ generation in H4-APP cells (Xie et al., 2006a). We next asked whether these effects are dependent on caspase activation. For this purpose, we incubated H4-APP cells with Z-VAD $(100 \mu \mathrm{M})$, a caspase inhibitor, for $1 \mathrm{~h}$, followed by treatment with $2 \%$ isoflurane for $6 \mathrm{~h}$. Isoflurane induced caspase- 3 activation, which was blocked by treatment with Z-VAD (Fig. $2 A)$. Quantification of the Western blots, based on the ratio of caspase- 3 fragment to FL caspase-3, revealed that treatment with $2 \%$ isoflurane induced caspase- 3 activation by $350 \%$ over that of control cells (Fig. $2 B,{ }^{* *} p<0.01$ ). Treatment with isoflurane and $\mathrm{Z}-\mathrm{VAD}$ reduced caspase-3 activation from 350 to $151 \%$ (Fig. $2 B$, $\left.{ }^{\# \#} p<0.01\right)$. Treatment with Z-VAD also attenuated isoflurane-induced alterations in APP processing and $\mathrm{A} \beta$ generation. As can be seen in Figure $2 C$, APP immunoblotting revealed that isoflurane treatment (lanes 5, 6) decreased protein levels of APP-FL and APP-CTFs, compared with the control cells (lanes 1, 2). Z-VAD (lanes 7, 8) suppressed these decreases in levels of APP-FL and APP-CTFs induced by isoflurane, whereas Z-VAD treatment alone (lanes 3,4) did not alter APP-FL and APP-CTF protein levels (Fig. 2C). Quantification of the Western blots showed that treatment with isoflurane (black bar) led to a $35 \%$ reduction in levels of APP-FL (Fig. 2D) and 51\% reduction in levels of APP-CTFs (Fig. 2E). Treatment with isoflurane plus $\mathrm{Z}-\mathrm{VAD}$ (striped bar) resulted in only a $10 \%$ decrease in protein levels of APP-FL (Fig. 2D) and a 12\% decrease in protein levels of APP-CTFs (Fig. 2E). Isoflurane treatments, but not Z-VAD treatment, significantly increased $A \beta$ levels in the conditioned media, whereas treatment with isoflurane plus Z-VAD (striped bar) led to smaller increases in A $\beta$ levels (157\%) versus treatment with isoflurane alone (black bar; 204\%) (Fig. 2 F) compared with control conditions (white bar). These results indicate that isoflurane-induced alterations in APP processing and A $\beta$ generation are dependent on the ability of isoflurane to induce caspase- 3 activation and apoptosis.

\section{Isoflurane enhances levels of BACE and $\gamma$-secretase in H4-APP cells}

Given that $2 \%$ isoflurane can induce apoptosis and increase $\mathrm{A} \beta$ generation, we next asked whether isoflurane can increase the levels of the amyloidogenic secretases, BACE and $\gamma$-secretase, in H4-APP cells. Treatment with 2\% isoflurane for $6 \mathrm{~h}$ increased caspase- 3 activation and simultaneously increased the levels of BACE. The level of APP-FL was also decreased by isofluraneinduced caspase activation (Fig. $3 A, B$ ). Next, we assessed the effects of isoflurane on the levels of nicastrin, a $\gamma$-secretase complex component, in H4-APP cells. Treatment with $2 \%$ isoflurane
B

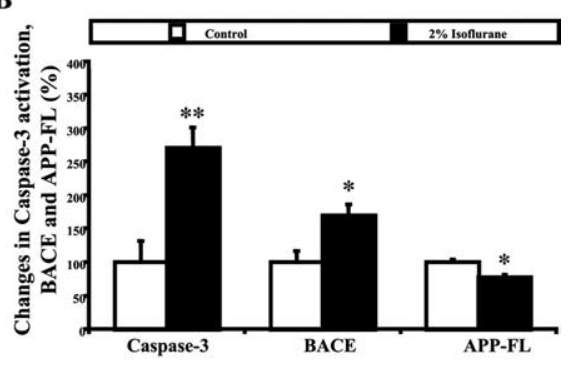

D

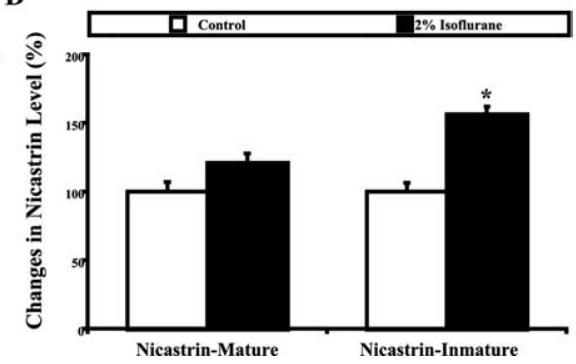

Figure 3. Isoflurane increases levels of BACE and nicastrin in H4-APP cells. $\boldsymbol{A}$, Treatment with $2 \%$ isoflurane (lane 1 ) induces

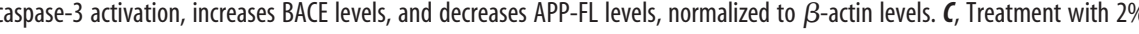
control condition and $2 \%$ isoflurane treatment $\left({ }^{*} p<0.05 ;{ }^{* *} p<0.01\right)$

increased protein levels of mature (121\%) and immature (156\%) nicastrin compared with the control cells (Fig. 3C,D).

\section{A $\beta$ aggregation inhibitors, iA $\beta 5$ and clioquinol, attenuate} isoflurane-induced caspase- 3 activation

Isoflurane has previously been shown to enhance $A \beta$ aggregation (Eckenhoff et al., 2004). Thus, we next tested whether A $\beta$ aggregation can potentiate the effects of isoflurane on caspase- 3 activation and apoptosis. For this purpose, we set out to assess the effects of two known $A \beta$ aggregation inhibitors, the $\beta$-sheet breaker peptide iA $\beta 5$ (Soto et al., 1998) and the metal protein attenuation compound (MPAC), clioquinol (Cherny et al., 2001), on isoflurane-induced caspase-3 activation. H4-APP cells were incubated with iA $\beta 5(1.5 \mu \mathrm{g} / \mu \mathrm{l})$ or clioquinol $(1 \mu \mathrm{M})$ for $1 \mathrm{~h}$, followed by treatment with $2 \%$ isoflurane or $100 \mathrm{~nm}$ STS for $6 \mathrm{~h}$. Treatment with $2 \%$ isoflurane alone induced caspase- 3 activation in H4-APP cells (Fig. $4 A, B$ ). iA $\beta 5$ plus $2 \%$ isoflurane treatment reduced caspase- 3 activation relative to the treatment with isoflurane alone (170 vs $247 \%$ ) (Fig. $4 A, B$ ). In contrast, iA $\beta 5$ treatment did not attenuate STS-induced caspase- 3 activation in H4-APP cells. iA $\beta 5$ alone did not induce caspase- 3 activation; treatment with either STS or STS plus iA $\beta 5$ led to similar increases in caspase- 3 activation (1200 vs $1250 \%$ ) (Fig. $4 C, D$ ). These results suggest that iA $\beta 5$ selectively attenuates isofluraneinduced, but not STS-induced, caspase-3 activation.

We next tested the ability of clioquinol to attenuate isoflurane-induced caspase activation in the H4-APP cells. Treatment with clioquinol alone did not increase caspase- 3 cleavage (Fig. $4 E, F$ ). Both $2 \%$ isoflurane and STS induced caspase- 3 activation. Treatment with $2 \%$ isoflurane plus clioquinol reduced caspase- 3 activation relative to treatment with $2 \%$ isoflurane 
A

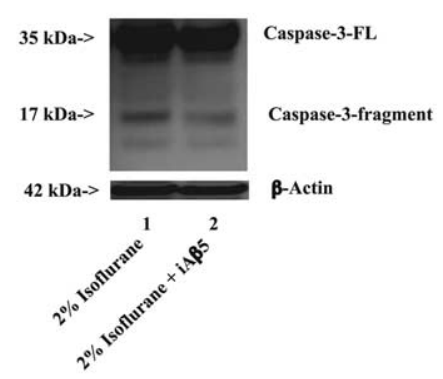

C

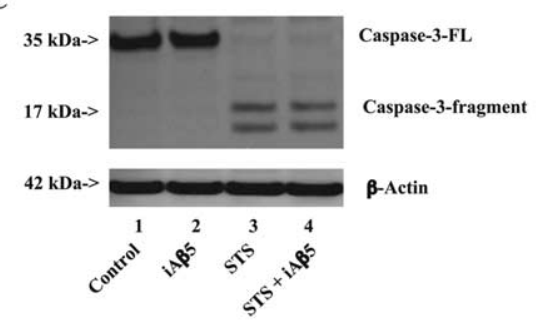

$\mathbf{E}$

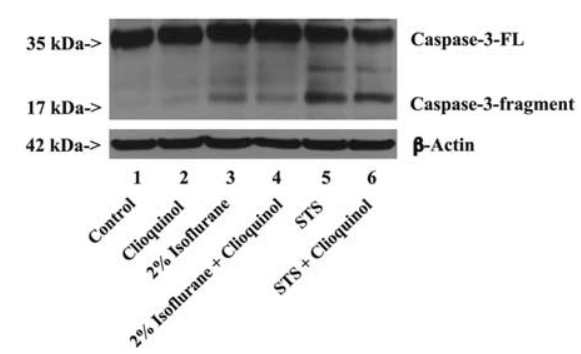

B

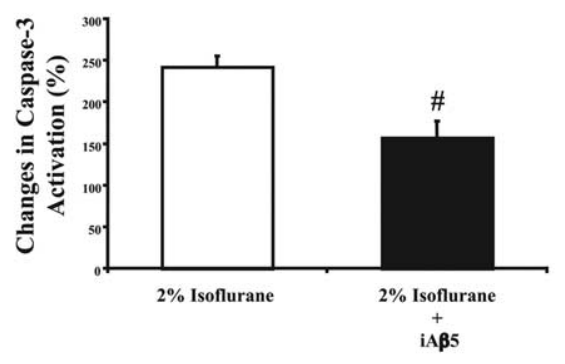

D

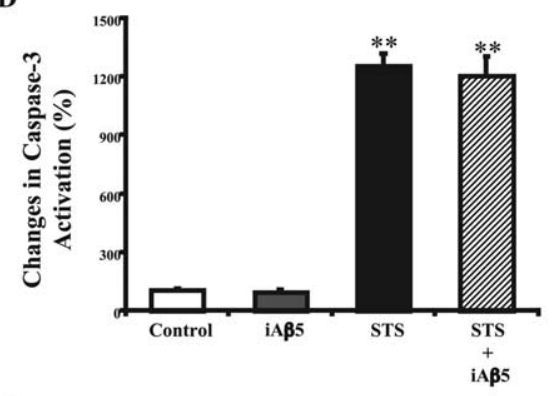

$\mathbf{F}$

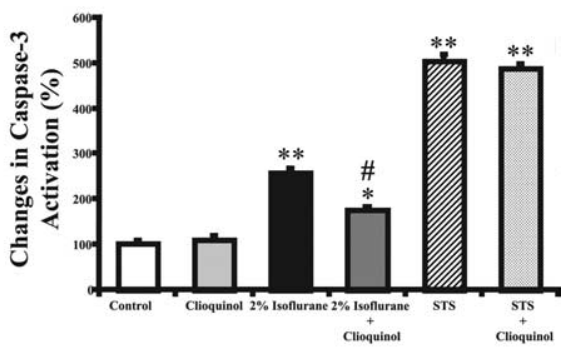

Figure 4. iA $\beta 5$ and clioquinol specifically attenuate isoflurane-induced caspase- 3 activation in H4-APP cells. A, iA $\beta 5$ plus $2 \%$ isoflurane treatment (lane 2 ) results in a lower degree of caspase- 3 cleavage than $2 \%$ isoflurane treatment alone (lane 1). There is no significant difference in the amounts of $\beta$-actin between the $2 \%$ is oflurane- and iA $\beta 5$ plus $2 \%$ isoflurane-treated H4-APP cells. $B$, Quantification of the Western blot, based on the ratio of caspase- 3 fragment to caspase- $3 \mathrm{FL}$, shows that iA $\beta 5$ treatment (black bar) reduces the isoflurane-induced caspase-3 activation (white bar), normalized to $\beta$-actin levels. C, STS treatment (lane 3), but not iA $\beta 5$ treatment (lane 2), causes caspase-3 activation compared with control condition (lane 1) in H4-APP cells. iA $\beta 5$ plus STS treatment (lane 4) leads to a degree of caspase-3 activation similar to STS treatment alone (lane 3). There is no significant difference in the amounts of $\beta$-actin in the control-, iA $\beta 5$-, STS-, or iA $\beta 5$ plus STS-treated H4-APP cells. D, Quantification of the Western blot shows that iA $\beta 5$ (striped bar) does not reduce the STS-induced (black bar) caspase-3 activation, normalized to $\beta$-actin levels. $\boldsymbol{E}$, Two percent isoflurane (lane 3) or STS (lane 5) treatment causes caspase-3 activation compared with control condition (lane 1) or clioquinol treatment (lane 2) in H4-APP cells. Clioquinol plus 2\% isoflurane treatment (lane 4) leads to a lower degree of caspase-3 activation than $2 \%$ isoflurane treatment alone (lane 3). Clioquinol plus STS treatment (lane 6) leads to a degree of caspase-3 activation similar to STS treatment alone (lane 5). There is no significant difference in the amounts of $\beta$-actin in all of the above treatments in H4-APP cells. $\boldsymbol{F}$, Quantification of the Western blot shows that clioquinol reduces the isofluraneinduced (gray bar vs black bar), but not STS-induced (dotted bar vs striped bar), caspase-3 activation, normalized to $\beta$-actin levels. Data are means $\pm S D ; n=3$ for each experimental group. $t$ test was used to compare the difference of caspase- 3 activation between control condition and STS or $2 \%$ isoflurane treatment $\left({ }^{*} p<0.05 ;{ }^{* *} p<0.01\right)$ and between saline treatment and iA $\beta 5$ or clioquinol treatment $\left({ }^{\#} p<0.05\right)$.

alone (174 vs 257\%) (Fig. 4E, F). In contrast, treatment with STS alone or STS plus clioquinol led to similar increases in caspase-3 activation ( 487 vs $501 \%$ ) (Fig. $4 E, F)$. Thus, both $\mathrm{A} \beta$ aggregation inhibitors, $\mathrm{iA} \beta 5$ and clioquinol, selectively attenuated isofluraneinduced, but not STS-induced, caspase-3 activation. These findings suggest that $A \beta$ aggregation can potentiate the ability of isoflurane to induce caspase- 3 activation.

\section{Exogenously added $\mathrm{A} \boldsymbol{\beta}$ can potentiate isoflurane-induced caspase- 3 activation}

Given that that $\mathrm{A} \beta$ aggregation potentiates isoflurane-induced caspase- 3 activation, we next asked whether exogenously added
$\mathrm{A} \beta$ can potentiate isoflurane-induced caspase activation. Naive $\mathrm{H} 4$ cells were incubated with $\mathrm{A} \beta(2.5,5$, and $7.5 \mu \mathrm{M}$ both $\mathrm{A} \beta_{40}$ and $\mathrm{A} \beta_{42}$ ) for $1 \mathrm{~h}$, followed by treatment with $2 \%$ isoflurane for $6 \mathrm{~h}$. Both $2 \%$ isoflurane and $\mathrm{A} \beta$ alone induced caspase- 3 activation in naive $\mathrm{H} 4$ cells (Fig. $5 A, B)$. However, treatment with $\mathrm{A} \beta$ plus $2 \%$ isoflurane resulted in a greater degree of caspase-3 cleavage than either treatment alone, in a dose-dependent manner (469, 403, 612, and 1223\%) (Fig. 5A,B). These results suggest that exogenously added $\mathrm{A} \beta$ can potentiate the isofluraneinduced caspase- 3 activation in naive $\mathrm{H} 4$ cells.

\section{Discussion}

We have shown previously that the commonly used inhalation anesthetic isoflurane can induce cellular apoptosis and increase $\mathrm{A} \beta$ generation in $\mathrm{H} 4$-APP cells (Xie et al., 2006a). Here, we set out to assess whether the effects of isoflurane on apoptosis are linked to $\mathrm{A} \beta$ generation and aggregation. First, we found that isoflurane can induce caspase- 3 activation in naive $\mathrm{H} 4$ cells without significantly affecting APP processing and $A \beta$ generation (Fig. 1). This indicates that isoflurane-induced apoptosis can occur independently of alterations in APP processing and A $\beta$ generation. However, it is still possible that isoflurane may lead to undetectable changes in APP processing and A $\beta$ generation in naive $\mathrm{H} 4$ cells.

Next, we examined whether isoflurane-induced alterations in APP processing and $A \beta$ generation are dependent on isoflurane-induced apoptosis. Using the broad caspase activation inhibitor, Z-VAD, we were able to show that inhibition of isoflurane-induced caspase- 3 activation was coupled to inhibition of the effects of isoflurane on APP processing and $\mathrm{A} \beta$ generation (Fig. 2). These findings revealed that the isoflurane-induced alterations in APP processing and A $\beta$ generation are largely dependent on the ability of isoflurane to induce apoptosis. Collectively, these findings suggest that isoflurane can induce caspase- 3 activation and apoptosis, which, in turn, alter APP processing and increase A $\beta$ generation. In contrast, isoflurane was able to induce apoptosis in the absence of any detectable effects on APP processing and A $\beta$ generation.

In exploring the mechanism by which isoflurane increases $\mathrm{A} \beta$ generation, we tested the effects of isoflurane on the amyloidogenic secretases, BACE and $\gamma$-secretase. We showed that treatment of H4-APP cells with $2 \%$ isoflurane for $6 \mathrm{~h}$ was able to enhance protein levels of the BACE and $\gamma$-secretase complex component nicastrin (Fig. 3). These findings suggest that isoflurane-induced apoptosis is linked to increases in the levels of 
A

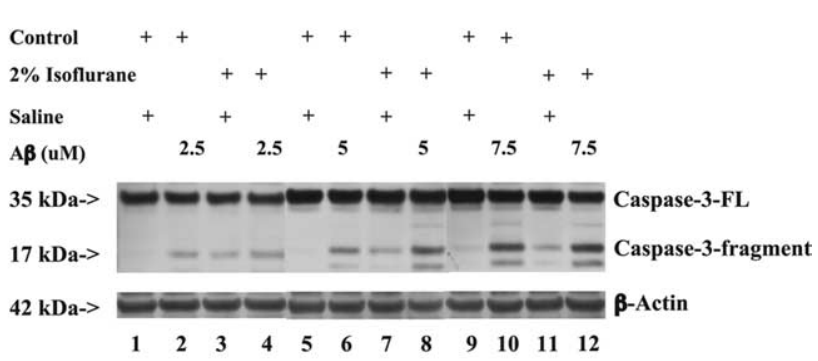

B

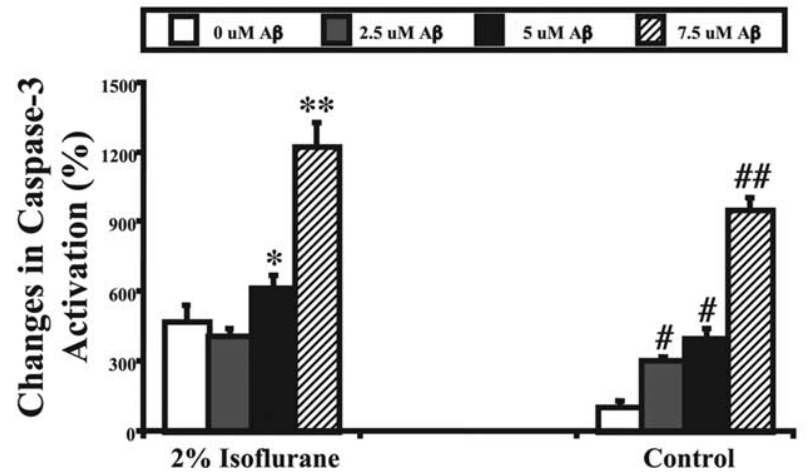

Figure 5. $A \beta$ potentiates the isoflurane-induced caspase-3 activation in $\mathrm{H} 4$ naive cells. $A$, Treatments with $2 \%$ isoflurane (lanes $3,7,11$ ) cause caspase-3 cleavage (activation) compared with control conditions (lanes $1,5,9)$ in $\mathrm{H} 4$ naive cells. $A \beta$ plus $2 \%$ isoflurane treatment (lanes $4,8,12$ ) leads to a greater degree of caspase- 3 cleavage than $2 \%$ isoflurane treatment alone (lanes $3,7,11$ ) in a dose-dependent manner. $A \beta$ treatments alone (lanes $2,6,10$ ) also cause caspase-3 activation compared with saline treatments (lanes $1,5,9)$ in a dose-dependent manner. There is no significant difference in the amounts of $\beta$-actin between the control- or $2 \%$ isoflurane-treated H4-APP cells. $\boldsymbol{B}$, Quantification of the Western blot shows that $A \beta[0$ (white bar), 2.5 (gray bar), 5 (black bar), and $7.5 \mu \mathrm{m}$ (striped bar)] induces caspase-3 activation and potentiates the isoflurane-induced caspase-3 activation in a dose-dependent manner, normalized to $\beta$-actin levels. Data are means $\pm S D ; n=3$ for each experimental group. $t$ test was used to compare the difference of caspase- 3 activation between saline and $A \beta$ treatment in $2 \%$ isoflurane-treated cells $\left({ }^{*} p<0.05 ;{ }^{* *} p<0.01\right)$ and in cells with the control condition $\left({ }^{\#} p<\right.$ $0.05 ;{ }^{\# \#} p<0.01$ )

$\mathrm{BACE}$ and nicastrin, leading to elevated BACE and $\gamma$-secretase activity, as evidenced by enhanced levels of $A \beta$. In contrast, treatment with $2 \%$ isoflurane for $6 \mathrm{~h}$ did not alter the protein levels of the three other components of $\gamma$-secretase, PS-1, PEN-2, and $\mathrm{APH}-1$ (data not shown). It is possible that longer treatment time may be required to affect the levels of the other components of the $\gamma$-secretase complex.

Isoflurane has previously been shown to enhance $\mathrm{A} \beta$ aggregation and potentiate the cytotoxicity of $\mathrm{A} \beta$ (Eckenhoff et al., 2004). It has been reported that oligomeric and fibrillar species of $\mathrm{A} \beta$ are more neurotoxic (Pike et al., 1993; Lorenzo and Yankner, 1994; Lambert et al., 1998; Grace et al., 2002; Walsh et al., 2002; Wang et al., 2002; Kayed et al., 2003; Kim et al., 2003; De Felice et al., 2004). We have shown previously that an amyloid fibrilbinding dye, Congo red, which has been reported to inhibit $\mathrm{A} \beta$ fibrillar aggregation and to prevent neurotoxicity (Lorenzo and Yankner, 1994), can attenuate 2\% isoflurane-induced apoptosis. Thus, $A \beta$ aggregation induced by isoflurane may be able to further potentiate the proapoptotic effects of isoflurane (Xie et al., 2006b). To further explore this effect with more specific $A \beta$ aggregation inhibitors, we tested the ability of iA $\beta 5$, a $\beta$-sheet breaker peptide (Soto et al., 1998), and clioquinol, an MPAC

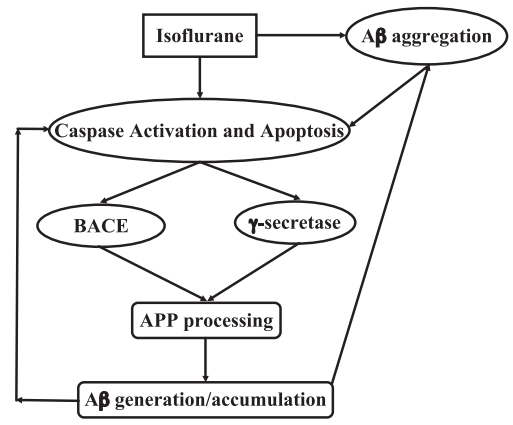

Figure 6. Hypothetical pathway by which isoflurane induces a vicious cycle of apoptosis and $A \beta$ generation and aggregation. Isoflurane induces caspase-3 activation/apoptosis. Caspase activation, in turn, increases the activities of both BACE and $\gamma$-secretase, which serve to increase $A \beta$ generation/accumulation. Isoflurane also enhances $A \beta$ aggregation, which further induces caspase- 3 activation and apoptosis. Elevated $A \beta$ generation/accumulation and $A \beta$ aggregation then further induce apoptosis, leading to a vicious cycle of isoflurane-induced apoptosis and $A \beta$ generation/accumulation and aggregation.

(Cherny et al., 2001), to attenuate isoflurane-induced apoptosis. We found that both compounds were able to attenuate the $2 \%$ isoflurane-induced apoptosis. The effects were also specific for isoflurane, because neither compound attenuated STS-induced apoptosis. Given that both iA $\beta 5$ and clioquinol have been reported to inhibit A $\beta$ aggregation (Soto et al., 1998; Cherny et al., 2001), these findings suggest that isoflurane-induced apoptosis can be potentiated by A $\beta$ aggregation. Finally, testing for the possibility of a vicious cycle of isoflurane-induced apoptosis and $\mathrm{A} \beta$ accumulation, we found that exogenously added $\mathrm{A} \beta$ potentiated isoflurane-induced caspase- 3 activation in a dosedependent manner in naive $\mathrm{H} 4$ cells. These findings suggest that the increased $\mathrm{A} \beta$ generation induced by isoflurane can further potentiate the isoflurane-induced apoptosis, leading to a vicious cycle.

Collectively, our studies defined the molecular pathways by which isoflurane induces apoptosis, alters APP processing, increases $A \beta$ levels, and enhances $A \beta$ aggregation. As can be seen in Figure 6, our studies illustrate that isoflurane can induce caspase activation and apoptosis, which then increase the activities of $\mathrm{BACE}$ and $\gamma$-secretase. The enhanced BACE and $\gamma$-secretase will be able to facilitate the APP processing to increase $\mathrm{A} \beta$ generation/ accumulation. Finally, the increased $\mathrm{A} \beta$ generation/accumulation will potentiate the isoflurane-induced caspase activation and apoptosis.

Alternatively, isoflurane may induce the cycle of apoptosis and $\mathrm{A} \beta$ generation/accumulation by first promoting $\mathrm{A} \beta$ aggregation, especially because isoflurane has previously been reported to induce $A \beta$ aggregation (Eckenhoff et al., 2004). Moreover, in the present study, we found that iA $\beta 5$ and clioquinol, effective inhibitors of $A \beta$ aggregation, specifically attenuated isofluraneinduced apoptosis. Collectively, our studies have shown that isoflurane can induce a vicious cycle of apoptosis and $\mathrm{A} \beta$ generation/accumulation and aggregation, followed by additional rounds of apoptosis, ultimately leading to cell death. These findings suggest that patients with elevated $A \beta$ levels could be more vulnerable to isoflurane-induced cytotoxicity.

It is possible that the elevated $A \beta$ levels are also associated with postoperative cognitive dysfunction, a subtle form of dementia after surgery and anesthesia (Xie and Tanzi, 2006). Additional investigation will be necessary to determine whether occurrences of postoperative cognitive dysfunction are linked to elevated $\mathrm{A} \beta$ levels in the human brain, CSF, and plasma. 
Isoflurane induces apoptosis, which, in turn, increases BACE levels in both naive H4 cells and H4-APP cells. However, the effects on APP processing and A $\beta$ generation are only detectable in H4-APP cells that contain sufficient levels of APP.

The molecular mechanism by which isoflurane induces apoptosis remains unclear and is an important topic for future studies. Previous studies have shown that isoflurane can induce calcium release from endoplasmic reticulum (ER) in cerebrocortical and hippocampal neurons (Kindler et al., 1999). Wei et al. (2005) reported that dantrolene, a selective ryanodine receptor antagonist that inhibits calcium release from ER, can suppress isoflurane-induced cytotoxicity. These findings suggest that isoflurane may induce cellular apoptosis by facilitating calcium release from ER. A $\beta$ has also been shown to elevate basal intracellular calcium levels and facilitate calcium overload after activation of glutamate receptors (Mattson et al., 1992; Mark et al., 1995) (for review, see Mattson and Chan, 2003). Furthermore, dantrolene has also been shown to inhibit $\mathrm{A} \beta$-induced cytotoxicity (Guo et al., 1997). Thus, these findings suggest that isoflurane can induce apoptosis by facilitating calcium release from ER to elevate intracellular calcium levels. Aggregated A $\beta$ may then potentiate isoflurane-induced apoptosis by further enhancing the intracellular calcium concentration. Future studies will be necessary to assess whether the effects of isoflurane and $\mathrm{A} \beta$ on cell death are mediated by cellular calcium homeostasis (Yoo et al., 2000).

Although our findings and the results from other studies suggest that isoflurane may affect $\mathrm{AD}$ neuropathogenesis, these experiments were performed only in cultured cells. The determination of the in vivo relevance of isoflurane on $\mathrm{AD}$ neuropathogenesis will be necessary before we can conclude that the inhalation anesthetic isoflurane facilitates or exacerbates $\mathrm{AD}$ neuropathogenesis in humans.

In conclusion, we found that isoflurane can induce both apoptosis and changes in APP processing, leading to increased generation of $A \beta$. Increased levels of $A \beta$ generation and subsequent aggregation induced by isoflurane can further potentiate isoflurane-induced apoptosis, forming a vicious cycle of apoptosis and $\mathrm{A} \beta$ generation/accumulation and aggregation. These studies should facilitate future strategies for delivering safer anesthesia care to patients, especially senior patients, who are particularly susceptible to the incidence of postoperative cognitive dysfunction and risk for AD.

\section{References}

Cherny RA, Atwood CS, Xilinas ME, Gray DN, Jones WD, McLean CA, Barnham KJ, Volitakis I, Fraser FW, Kim Y, Huang X, Goldstein LE, Moir RD, Lim JT, Beyreuther K, Zheng H, Tanzi RE, Masters CL, Bush AI (2001) Treatment with a copper-zinc chelator markedly and rapidly inhibits beta-amyloid accumulation in Alzheimer's disease transgenic mice. Neuron 30:665-676.

De Felice FG, Vieira MN, Saraiva LM, Figueroa-Villar JD, Garcia-Abreu J, Liu R, Chang L, Klein WL, Ferreira ST (2004) Targeting the neurotoxic species in Alzheimer's disease: inhibitors of Abeta oligomerization. FASEB J 18:1366-1372.

Eckenhoff RG, Johansson JS, Wei H, Carnini A, Kang B, Wei W, Pidikiti R, Keller JM, Eckenhoff MF (2004) Inhaled anesthetic enhancement of amyloid-beta oligomerization and cytotoxicity. Anesthesiology 101:703-709.

Florent S, Malaplate-Armand C, Youssef I, Kriem B, Koziel V, Escanye MC, Fifre A, Sponne I, Leininger-Muller B, Olivier JL, Pillot T, Oster T (2006) Docosahexaenoic acid prevents neuronal apoptosis induced by soluble amyloid-beta oligomers. J Neurochem 96:385-395.

Francis R, McGrath G, Zhang J, Ruddy DA, Sym M, Apfeld J, Nicoll M, Maxwell M, Hai B, Ellis MC, Parks AL, Xu W, Li J, Gurney M, Myers RL, Himes CS, Hiebsch R, Ruble C, Nye JS, Curtis D (2002) aph-1 and pen-2 are required for Notch pathway signaling, gamma-secretase cleavage of betaAPP, and presenilin protein accumulation. Dev Cell 3:85-97.

Galli C, Piccini A, Ciotti MT, Castellani L, Calissano P, Zaccheo D, Tabaton M (1998) Increased amyloidogenic secretion in cerebellar granule cells undergoing apoptosis. Proc Natl Acad Sci USA 95:1247-1252.

Gervais FG, Xu D, Robertson GS, Vaillancourt JP, Zhu Y, Huang J, LeBlanc A, Smith D, Rigby M, Shearman MS, Clarke EE, Zheng H, Van Der Ploeg LH, Ruffolo SC, Thornberry NA, Xanthoudakis S, Zamboni RJ, Roy S, Nicholson DW (1999) Involvement of caspases in proteolytic cleavage of Alzheimer's amyloid-beta precursor protein and amyloidogenic A beta peptide formation. Cell 97:395-406.

Glenner GG, Wong CW (1984) Alzheimer's disease and Down's syndrome: sharing of a unique cerebrovascular amyloid fibril protein. Biochem Biophys Res Commun 122:1131-1135.

Grace EA, Rabiner CA, Busciglio J (2002) Characterization of neuronal dystrophy induced by fibrillar amyloid beta: implications for Alzheimer's disease. Neuroscience 114:265-273.

Gu Y, Misonou H, Sato T, Dohmae N, Takio K, Ihara Y (2001) Distinct intramembrane cleavage of the beta-amyloid precursor protein family resembling gamma-secretase-like cleavage of Notch. J Biol Chem 276:35235-35238.

Guo Q, Sopher BL, Furukawa K, Pham DG, Robinson N, Martin GM, Mattson MP (1997) Alzheimer's presenilin mutation sensitizes neural cells to apoptosis induced by trophic factor withdrawal and amyloid $\beta$-peptide: involvement of calcium and oxyradicals. J Neurosci 17:4212-4222.

Holtzman DM, Deshmukh M (1997) Caspases: a treatment target for neurodegenerative disease? Nat Med 3:954-955.

Jendroska K, Hoffmann OM, Patt S (1997) Amyloid beta peptide and precursor protein (APP) in mild and severe brain ischemia. Ann NY Acad Sci 826:401-405.

Kalaria RN (2000) The role of cerebral ischemia in Alzheimer's disease. Neurobiol Aging 21:321-330.

Kayed R, Head E, Thompson JL, McIntire TM, Milton SC, Cotman CW, Glabe CG (2003) Common structure of soluble amyloid oligomers implies common mechanism of pathogenesis. Science 300:486-489.

Kim HJ, Chae SC, Lee DK, Chromy B, Lee SC, Park YC, Klein WL, Krafft GA, Hong ST (2003) Selective neuronal degeneration induced by soluble oligomeric amyloid beta protein. FASEB J 17:118-120.

Kindler CH, Eilers H, Donohoe P, Ozer S, Bickler PE (1999) Volatile anesthetics increase intracellular calcium in cerebrocortical and hippocampal neurons. Anesthesiology 90:1137-1145.

Kokmen E, Whisnant JP, O'Fallon WM, Chu CP, Beard CM (1996) Dementia after ischemic stroke: a population-based study in Rochester, Minnesota (1960-1984). Neurology 46:154-159.

Kriem B, Sponne I, Fifre A, Malaplate-Armand C, Lozac'h-Pillot K, Koziel V, Yen-Potin FT, Bihain B, Oster T, Olivier JL, Pillot T (2005) Cytosolic phospholipase A2 mediates neuronal apoptosis induced by soluble oligomers of the amyloid-beta peptide. FASEB J 19:85-87.

Lambert MP, Barlow AK, Chromy BA, Edwards C, Freed R, Liosatos M, Morgan TE, Rozovsky I, Trommer B, Viola KL, Wals P, Zhang C, Finch CE, Krafft GA, Klein WL (1998) Diffusible, nonfibrillar ligands derived from Abeta1-42 are potent central nervous system neurotoxins. Proc Natl Acad Sci USA 95:6448-6453.

LeBlanc A (1995) Increased production of $4 \mathrm{kDa}$ amyloid $\beta$ peptide in serum deprived human primary neuron cultures: possible involvement of apoptosis. J Neurosci 15:7837-7846.

LeBlanc A, Liu H, Goodyer C, Bergeron C, Hammond J (1999) Caspase-6 role in apoptosis of human neurons, amyloidogenesis, and Alzheimer's disease. J Biol Chem 274:23426-23436.

Li YM, Lai MT, Xu M, Huang Q, DiMuzio-Mower J, Sardana MK, Shi XP, Yin KC, Shafer JA, Gardell SJ (2000) Presenilin 1 is linked with gammasecretase activity in the detergent solubilized state. Proc Natl Acad Sci USA 97:6138-6143.

Lorenzo A, Yankner BA (1994) Beta-amyloid neurotoxicity requires fibril formation and is inhibited by Congo red. Proc Natl Acad Sci USA 91:12243-12247.

Lunkes A, Trottier Y, Mandel JL (1998) Pathological mechanisms in Huntington's disease and other polyglutamine expansion diseases. Essays Biochem 33:149-163.

Mark RJ, Hensley K, Butterfield DA, Mattson MP (1995) Amyloid $\beta$-peptide impairs ion-motive ATPase activities: evidence for a role in loss of neuronal $\mathrm{Ca}^{2+}$ homeostasis and cell death. J Neurosci 15:6239-6249. 
Mattson MP, Chan SL (2003) Neuronal and glial calcium signaling in Alzheimer's disease. Cell Calcium 34:385-397.

Mattson MP, Cheng B, Davis D, Bryant K, Lieberburg I, Rydel RE (1992) $\beta$-Amyloid peptides destabilize calcium homeostasis and render human cortical neurons vulnerable to excitotoxicity. J Neurosci 12:376-389.

Nagy Z, Esiri MM, Jobst KA, Morris JH, King EM, McDonald B, Joachim C, Litchfield S, Barnetson L, Smith AD (1997) The effects of additional pathology on the cognitive deficit in Alzheimer disease. J Neuropathol Exp Neurol 56:165-170.

Namura S, Zhu J, Fink K, Endres M, Srinivasan A, Tomaselli KJ, Yuan J, Moskowitz MA (1998) Activation and cleavage of caspase-3 in apoptosis induced by experimental cerebral ischemia. J Neurosci 18:3659-3668.

Pike CJ, Burdick D, Walencewicz AJ, Glabe CG, Cotman CW (1993) Neurodegeneration induced by $\beta$-amyloid peptides in vitro: the role of peptide assembly state. J Neurosci 13:1676-1687.

Pillot T, Drouet B, Queille S, Labeur C, Vandekerchkhove J, Rosseneu M, Pincon-Raymond M, Chambaz J (1999) The nonfibrillar amyloid betapeptide induces apoptotic neuronal cell death: involvement of its C-terminal fusogenic domain. J Neurochem 73:1626-1634.

Sastre M, Steiner H, Fuchs K, Capell A, Multhaup G, Condron MM, Teplow DB, Haass C (2001) Presenilin-dependent gamma-secretase processing of beta-amyloid precursor protein at a site corresponding to the $\mathrm{S} 3$ cleavage of Notch. EMBO Rep 2:835-841.

Snowdon DA, Greiner LH, Mortimer JA, Riley KP, Greiner PA, Markesbery WR (1997) Brain infarction and the clinical expression of Alzheimer disease. The Nun Study. JAMA 277:813-817.

Sodhi CP, Rampalli S, Perez RG, Koo EH, Quinn B, Gottardi-Littell NR (2004) The endocytotic pathway is required for increased A beta 42 secretion during apoptosis. Brain Res Mol Brain Res 128:201-211.

Soto C, Sigurdsson EM, Morelli L, Kumar RA, Castano EM, Frangione B (1998) Beta-sheet breaker peptides inhibit fibrillogenesis in a rat brain model of amyloidosis: implications for Alzheimer's therapy. Nat Med 4:822-826.

Sponne I, Fifre A, Drouet B, Klein C, Koziel V, Pincon-Raymond M, Olivier JL, Chambaz J, Pillot T (2003) Apoptotic neuronal cell death induced by the non-fibrillar amyloid-beta peptide proceeds through an early reactive oxygen species-dependent cytoskeleton perturbation. J Biol Chem 278:3437-3445.

Steiner H, Winkler E, Edbauer D, Prokop S, Basset G, Yamasaki A, Kostka M, Haass C (2002) PEN-2 is an integral component of the gamma-secretase complex required for coordinated expression of presenilin and nicastrin. J Biol Chem 277:39062-39065.

Tanzi RE, Bertram L (2005) Twenty years of the Alzheimer's disease amyloid hypothesis: a genetic perspective. Cell 120:545-555.

Tesco G, Koh YH, Tanzi RE (2003) Caspase activation increases betaamyloid generation independently of caspase cleavage of the betaamyloid precursor protein (APP). J Biol Chem 278:46074-46080.
Thornberry NA (1998) Caspases: key mediators of apoptosis. Chem Biol 5:R97-R103.

Walsh DM, Klyubin I, Fadeeva JV, Rowan MJ, Selkoe DJ (2002) Amyloidbeta oligomers: their production, toxicity and therapeutic inhibition. Biochem Soc Trans 30:552-557.

Wang HW, Pasternak JF, Kuo H, Ristic H, Lambert MP, Chromy B, Viola KL, Klein WL, Stine WB, Krafft GA, Trommer BL (2002) Soluble oligomers of beta amyloid (1-42) inhibit long-term potentiation but not long-term depression in rat dentate gyrus. Brain Res 924:133-140.

Wei H, Kang B, Wei W, Liang G, Meng QC, Li Y, Eckenhoff RG (2005) Isoflurane and sevoflurane affect cell survival and BCL-2/BAX ratio differently. Brain Res 1037:139-147.

Xie Z, Tanzi RE (2006) Alzheimer's disease and post-operative cognitive dysfunction. Exp Gerontol 41:346-359.

Xie Z, Moir RD, Romano DM, Tesco G, Kovacs DM, Tanzi RE (2004) Hypocapnia induces caspase-3 activation and increases abeta production. Neurodegener Dis 1:29-37.

Xie Z, Romano DM, Tanzi RE (2005a) Effects of RNAi-mediated silencing of PEN-2, APH-1a, and nicastrin on wild-type vs FAD mutant forms of presenilin 1. J Mol Neurosci 25:67-77.

Xie Z, Romano DM, Tanzi RE (2005b) RNA interference-mediated silencing of X11alpha and X11beta attenuates amyloid beta-protein levels via differential effects on beta-amyloid precursor protein processing. J Biol Chem 280:15413-15421.

Xie Z, Dong Y, Maeda U, Alfille P, Culley DJ, Crosby G, Tanzi RE (2006a) The common inhalation anesthetic isoflurane induces apoptosis and increases amyloid beta protein levels. Anesthesiology 104:988-994.

Xie Z, Dong Y, Maeda U, Moir R, Inouye SK, Culley DJ, Crosby G, Tanzi RE (2006b) Isoflurane-induced apoptosis: a potential pathogenic link between delirium and dementia. J Gerontol A Biol Sci Med Sci 61A:1300-1306.

Yoo AS, Cheng I, Chung S, Grenfell TZ, Lee H, Pack-Chung E, Handler M, Shen J, Xia W, Tesco G, Saunders AJ, Ding K, Frosch MP, Tanzi RE, Kim TW (2000) Presenilin-mediated modulation of capacitative calcium entry. Neuron 27:561-572.

Yu C, Kim SH, Ikeuchi T, Xu H, Gasparini L, Wang R, Sisodia SS (2001) Characterization of a presenilin-mediated amyloid precursor protein carboxyl-terminal fragment gamma. Evidence for distinct mechanisms involved in gamma-secretase processing of the APP and Notch1 transmembrane domains. J Biol Chem 276:43756-43760.

Yu G, Nishimura M, Arawaka S, Levitan D, Zhang L, Tandon A, Song YQ, Rogaeva E, Chen F, Kawarai T, Supala A, Levesque L, Yu H, Yang DS, Holmes E, Milman P, Liang Y, Zhang DM, Xu DH, Sato C, et al. (2000) Nicastrin modulates presenilin-mediated notch/glp-1 signal transduction and betaAPP processing. Nature 407:48-54. 